\title{
PENGEMBANGAN METODE APITU2K DALAM MEMECAHKAN MASALAH UNTUK MENINGKATKAN BERPIKIR KRITIS SISWA SMP
}

\author{
Jeje Sudarja ${ }^{1)}$ \\ ${ }^{1}$ SMP Negeri 1 Karangkancana, Kabupaten Kuningan Jawa Barat \\ Email : sudarja.jeje@yahoo.co.id
}

\begin{abstract}
APA Citation: Sudarja, J. (2019). Pengembangan Metode APITU2K Dalam Memecahkan Masalah Untuk Meningkatkan Berpikir Kritis Siswa Smp. Quagga: Jurnal Pendidikan dan Biologi, 11(2), 65-72. doi: 10.25134/quagga.v11i2.1841.
\end{abstract}

Received: 27-06-2019

Accepted: 25-07-2019

Published: 26-07-2019

\begin{abstract}
Penelitian dilatarbelakangi belum optimalnya berpikir kritis siswa dalam memecahkan masalah indra penglihatan manusia. Oleh karena itu dikembangkan metode yang dapat memfasilitasi berkembangnya kemampuan berpikir kritis. Metode tersebut adalah APITU2K (Amati, PIkirkan, TUliskan, Komunikasikan, Kritikan). Penelitian bertujuan 1. Untuk menghasilkan bentuk metode APITU2K dalam memecahkan masalah indra penglihatan manusia. 2. Untuk mengetahui berpikir kritis siswa kelas IX C SMPN 1 Karangkancana tahun pelajaran 2018/2019 melalui metode APITU2K dalam memecahkan masalah indra penglihatan manusia. Metode penelitian adalah Research and Development. Pada tahap pemakaian di kelas IX C dengan jumlah 28 siswa menggunakan one group pretest posttest design. Pengumpulan data pretes dan postes melalui tes berpikir kritis tentang indra penglihatan manusia. Data dianalisis untuk menentukan nilai rata-rata,

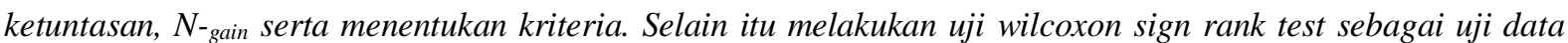
berpasangan pada kelompok tunggal untuk mengetahui perbedaan nilai pretes dan postes. Hasil penelitian adalah 1. Dihasilkan bentuk metode APITU2K dalam memecahkan masalah indra penglihatan manusia. 2. Hasil belajar berupa berpikir kritis siswa menunjukkan nilai rata-rata postes 75,31 dengan kriteria baik, ketuntasan 81,48\%, dan $\mathrm{N}$-gain sebesar 0,54 dengan kriteria sedang. Berdasarkan uji wilcoxon sign rank test nilai $Z$ sebesar -3.712 sehingga diputuskan terdapat perbedaan signifikan antara nilai pretes dan postes.
\end{abstract}

Kata kunci : metode APITU2K, masalah indra penglihatan manusia, berpikir kritis

Abstract: The research is motivated by the lack of optimal thinking of students in solving problems of human vision. Therefore methods are developed that can facilitate the development of critical thinking skills. The method is APITU2K (Observe, Declare, Illustrate, Communicate, Criticize). Research aims 1. To produce a form of the APITU2K method in solving human visual sensation problems. 2. To find out the critical thinking of class IX C students in Karangkancana 1 Junior High School 2018/2019 through the APITU2K method in solving human visual sensation problems. The research method is Research and Development. At the stage of use in class IX C with a total of 28 students using one group pretest posttest design. Collecting pretest and posttest data through tests of critical thinking about the human senses. Data were analyzed to determine the average value, completeness, $N$-gain and determine criteria. Besides doing the Wilcoxon sign rank test as a paired data test in a single group to determine the difference in the value of the pretest and posttest. The results of the study are 1. The APITU2K method results in solving human visual sense problems. 2. Learning outcomes in the form of critical thinking students show posttest average value 75.31 with good criteria, completeness $81.48 \%$, and $N$-gain of 0.54 with moderate criteria. Based on the Wilcoxon sign rank test the $Z$ value was -3,712 so it was decided that there were significant differences between the pretest and posttest scores.

Keywords: APITU2K method, human visual sense problems, critical thinking

\section{PENDAHULUAN}

Salah satu kemampuan abad 21 yang harus dimiliki siswa supaya siap menghadapi tantangan dan persaingan di masa depan adalah critical thinking (berpikir kritis). Menurut Ennis (2011), bahwa berpikir kritis adalah sebuah cara berpikir 
Quagga: Jurnal Pendidikan dan Biologi

Volume 11, Nomor 2, Juli 2019

yang beralasan dan refleksi dengan menekankan pada pembuatan keputusan tentang apa yang harus dipercayai atau dilakukan. Dalam berpikir kritis melibatkan aktivitas mental seperti memberikan argumen serta kritikan dalam penyempurnaan memecahkan suatu masalah. Pembelajaran di sekolah harus memberikan kesempatan yang seluas-luasnya bagi siswa untuk mengembangkan kemampuan berpikir kritis dalam memecahkan sebuah masalah.

Pembelajaran pada mata pelajaran IPA di SMP salah satunya menitikberatkan pada kemampuan berpikir krtis dalam memecahkan masalah melalui kerja ilmiah sebagai langkah dalam memecahkan masalah (Kemendikbud, 2013).

Pembelajaran indra pendengaran manusia di kelas IX C SMP Negeri 1 Karangkancana Kabupaten Kuningan tahun pelajaran 2018/2019 menunjukkan sebagian besar siswa belum maksimal dalam menyelesaikan tugas yang diberikan menggunakan kerja ilmiah seperti mengobservasi, memikirkan, menuliskan, mengkomunikasikan serta melakukan kritikan dalam memecahkan masalah. Selain itu, pembelajaran yang berlangsung belum optimal dalam mengembangkan kemampuan berpikir kritis. Sehingga hasil belajar belum memuaskan dengan perolehan nilai rata-rata 67 dan persentase ketuntasan hanya mencapai $54,72 \%$. Oleh karena itu diperlukan solusi untuk mengatasinya.

Pembelajaran yang mengembangkan kemampuan berpikir kritis dalam memecahkan masalah perlu dilatihkan. Dalam memecahkan masalah diperlukan cara kerja yang runtut agar masalah yang dipecahkan teridentifikasi dengan tepat. Cara kerja tersebut adalah kerja ilmiah. Yakni rangkaian langkah-langkah dalam memecahkan sebuah masalah yang melibatkan kognitif, psikomotor serta afektif untuk memfasilitasi berkembangnya berpikir kritis siswa sebagai tujuan dari pembelajaran. Kerja ilmiah adalah suatu proses yang dilakukan oleh siswa melalui cara ilmiah untuk mendapatkan jawaban dari suatu permasalahan. Menurut Rasmawan (2017), bahwa siswa perlu dilatih
p-ISSN 1907-3089, e-ISSN2651-5869

https://journal.uniku.ac.id/index.php/quagga

keterampilan kerja ilmiah dan berpikir kritisnya dalam memecahkan sebuah permasalahan yang terjadi dalam kehidupan sehari hari. Kerja ilmiah berupa langkah-langkah dalam memecahkan masalah yang memfasilitasi berkembangnya kemampuan berpikir kritis siswa meliputi Amati, PIkirkan, TUliskan, Komunikasikan, Kritikan selanjutnya disebut APITU2K. Kerja ilmiah tersebut mengacu pada kata kerja operasional taksonomi Bloom (UPI,2011).

Aktivitas mengamati merupakan langkah awal dalam memunculkan informasi tentang masalah yang dihadapi. Aktivitas ini melibatkan semua indra untuk mendapatkan informasi yang lengkap (Dahar, 2011). Pada aktivitas berpikir, siswa menentukan masalah utama yang akan dipecahkan berdasarkan situasi yang diberikan pada aktivitas mengamati (Khairah dkk, 2017). Selanjutnya pada aktivitas menuliskan hasil belajar dengan menggunakan bahasa sendiri sebagai bentuk pemahaman terhadap konsep dalam materi yang sedang dipelajari merupakan upaya meningkatkan keterlibatan semua siswa dalam kegiatan belajar dan juga aktivitas berpikir siswa (Siregar dkk, 2017). Pada aktivitas komunikasi akan melatih kemampuan siswa untuk memberdayakan keterampilan metakognitif yang mereka miliki. Aktivitas ini memberikan penekanan kepada siswa untuk mempresentasikan hasil tulisan (Hasan dkk, 2016). Sedangkan pada aktivitas kritikan merupakan sebuah kemampuan menjelaskan makna yang sesuai dengan bahasa yang jelas dan logis serta dapat mengaitkan dengan konsep yang benar tanpa memunculkan keraguan. Kemampuan memberikan masukan dan tanggapan yang konstruktif merupakan kerja ilmiah yang menekankan pada upaya menyusun argumen untuk melengkapi informasi. (Rasmawan, 2017).

Rumusan masalah adalah 1. Bagaimanakah bentuk metode APITU2K dalam memecahkan masalah indra penglihatan manusia?. 2. Apakah metode APITU2K dalam memecahkan masalah indra penglihatan dapat meningkatkan berpikir kritis siswa kelas IX C SMPN 1 Karangkancana tahun pelajaran 2018/2019 ?. Adapun tujuannya 
Quagga: Jurnal Pendidikan dan Biologi

Volume 11, Nomor 2, Juli 2019

adalah 1. Untuk menghasilkan bentuk metode APITU2K dalam memecahkan masalah indra penglihatan mansuia. 2. Untuk mengetahui berpikir kritis siswa kelas IX C SMPN 1 Karangkancana tahun pelajaran 2018/2019 tentang indra penglihatan manusia melalui penerapan metode APITU2K.

\section{METODOLOGI PENELITIAN}

Metode APITU2K dikembangkan melalui metode Research and Development (Sugiyono, 2012) dengan tahapan yang telah disederhanakan seperti terlihat pada Gambar 1.

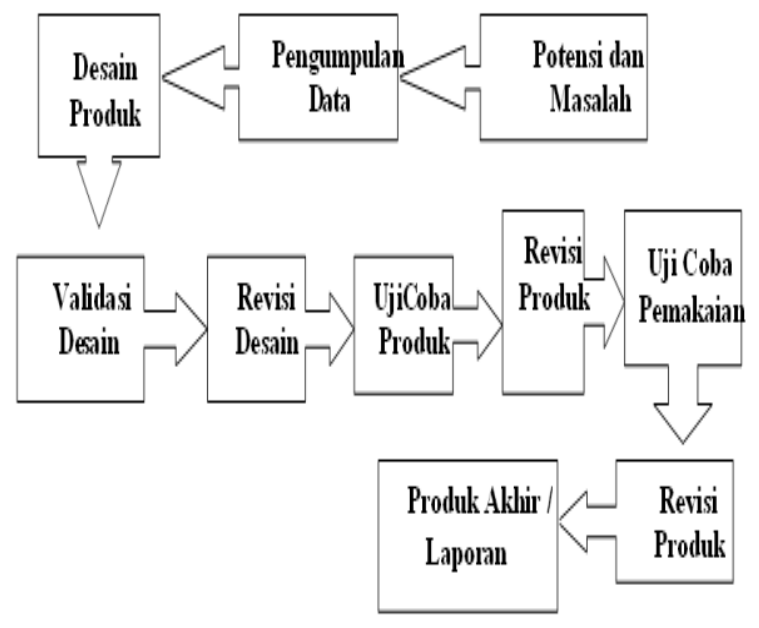

Gambar 1. Tahapan research and development

Tahap uji pemakaian pada kelas IX C yang berjumlah 28 siswa dengan desain penelitian ini adalah one group pretest posttest design (Sugiyono, 2012). Sampel penelitian diberi perlakuan metode APITU2K selama waktu tertentu. Pretes diberikan sebelum perlakuan, dan postes diberikan setelah perlakuan. Desain penelitian one group pretest-posttest adalah :

\begin{tabular}{ccc}
\hline Pretes & Perlakuan & Posttes \\
\hline $\mathrm{O}_{1}$ & $\mathrm{X}$ & $\mathrm{O}_{2}$ \\
\hline
\end{tabular}

Pengumpulkan data menggunakan tes untuk memperoleh data berpikir kritis siswa berbentuk tes uraian. Untuk setiap indikator diambil satu sub indikator saja, karena disesuaikan dengan tingkat relevansi dan perkembangan berpikir siswa SMP. Tes uraian berpikir kritis dengan
p-ISSN 1907-3089, e-ISSN2651-5869

https://journal.uniku.ac.id/index.php/quagga

melihat fase kemampuan berpikir kritis siswa (Ennis, 2011) yakni : (a) memberi penjelasan dasar dengan sub indikator mampu bertanya dan menjawab pertanyaan yang menantang, (b) membangun keterampilan dasar dengan indikator mengetahui resiko atau dampak/akibat, (c) menyimpulkan dengan indikator mampu memperkirakan atau membuat kesimpulan, (d) memberi penjelasan lanjut dengan indikator mampu mengidentifikasi istilah dan (e) mengatur strategi dan taktik dengan indikator memutuskan suatu tindakan yang harus dilakukan.

Data dianalisis untuk menentukan nilai ratarata, ketuntasan, $\mathrm{N}$-gain serta menentukan kriteria. Untuk menentukan signifikasi perbedaan nilai sebelum dan sesudah diterapkannya metode APITU2K dilakukan uji wilcoxon sign rank test sebagai uji statistik data berpasangan pada kelompok tunggal. Pengambilan keputusan untuk menentukan signifikasi dengan melihat probabilitas (asymptotic significance), jika < 0,05 berarti terdapat perbedaan yang signifikan dan jika > 0,05 berarti terdapat perbedaan yang tidak signifikan.

Untuk menentukan kriteria peningkatan berpikir kritis $(\mathrm{N}$-gain $)$, mengacu pada Tabel 1 .

Tabel 1. Kriteria Indeks Gain

\begin{tabular}{cc}
\hline Gain & Interpretasi \\
\hline $\mathrm{N}-$ gain $>0,70$ & Tinggi \\
$0,30<\mathrm{N}-$ gain $<0,70$ & Sedang \\
$\mathrm{N}-$ gain $\leq 0,30$ & Rendah \\
\hline
\end{tabular}

(Sumber : Rosdianto, 2017)

Untuk menentukan kriteria berpikir kritis siswa dengan cara membandingkannya dengan kriteria acuan yang tersaji pada Tabel 2 .

Tabel 2. Kriteria Berpikir Kritis Siswa

\begin{tabular}{cc}
\hline Presentase & Kriteria \\
\hline $90 \% \leq \mathrm{A}<100 \%$ & Sangat Baik \\
$70 \% \leq \mathrm{B}<90 \%$ & Baik \\
$55 \% \leq \mathrm{C}<70 \%$ & Cukup \\
$40 \% \leq \mathrm{D}<55 \%$ & Kurang \\
$0 \% \leq-\mathrm{E}<40 \%$ & Kurang Sekali \\
\hline
\end{tabular}

(Sumber : Rahayu, 2012) 
Quagga: Jurnal Pendidikan dan Biologi

Volume 11, Nomor 2, Juli 2019

\section{HASIL DAN PEMBAHASAN Pengembangan Metode APITU2K}

Pada tahap potensi dan masalah, teridentifikasi adanya dukungan sarana pembelajaran serta warga sekolah. Sedangkan masalah yang teridentifikasi adanya belum optimalnya pembelajaran yang melibatkan partisifasi aktif siswa. Keterampilan kerja ilmiah sebagai sebuah langkah dalam menyelesaikan masalah masih rendah. Hasil belajar berupa kemampuan berpikir kritis masih rendah dalam menyelasaikan masalah.

Pada tahap pengumpulan data, diperoleh keterlibatan / partisipasi siswa dalam pembelajaran masih minim. Sebagian besar siswa belum menyelesaikan tugas yang diberikan melalui kerja ilmiah. Masih membudaya cara belajar hafalan. Persentase ketuntasan 55,43\% dengan nilai rata-rata 68 .

Pada tahap desain produk tersusun metode APITU2K. Pembelajaran didesain dengan 3 fase yang berawal dari fase pendahuluan, inti dan penutup, seperti terlihat pada Gambar 2.

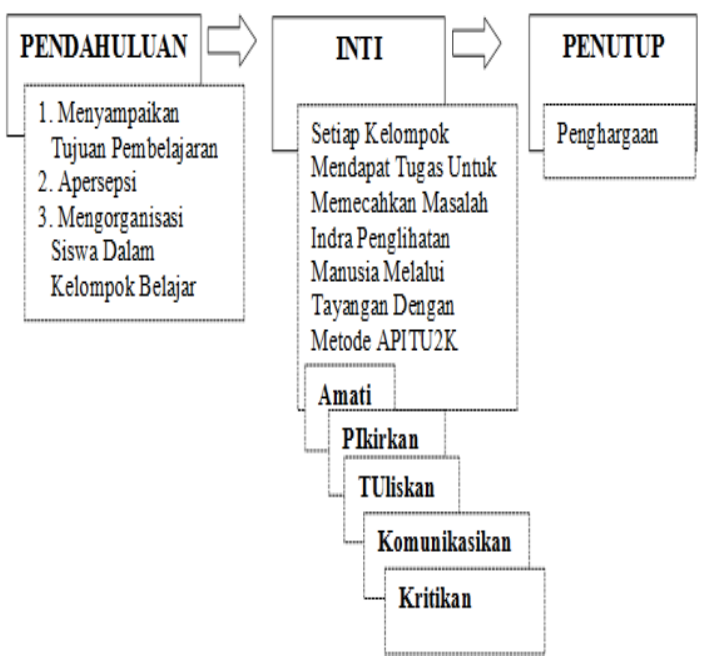

Gambar 2. Desain awal APITU2K

Definisi operasional metode APITU2K adalah pembelajaran secara berkelompok untuk memecahkan masalah dengan menggunakan kerja ilmiah sebagai metodenya. Kerja Ilmiah itu berupa Amati, PIkirkan, TUliskan, Komunikasikan, Kritikan (APITU2K). Adapun penjelasan dari setiap langkah kerja ilmiah APITU2K adalah Amati, setiap kelompok
p-ISSN 1907-3089, e-ISSN2651-5869

https://journal.uniku.ac.id/index.php/quagga

melakukan kegiatan pengamatan terhadap permasalah yang yang ditayangkan. Pikirkan, setiap kelompok melakukan kegiatan berpikir secara kritis terhadap masalah menyangkut apa, mengapa dan bagaimana (melakukan diskusi). Tuliskan, setiap kelompok melalukan kegiatan menulis tentang hasil diskusi pada langkah pikirkan. Komunikasikan, hasil diskusi kelompok kemudian dipresentasi di depan kelompok lain dan Kritikan, setiap kelompok memberikan kritikan / masukan yang konstruktif terhadap hasil kerja kelompok lain yang telah dipresentasikan.

Pada tahap validasi desain, validasi dilakukan oleh praktisi pendidikan (guru IPA) untuk menguji kevalidan produk sebelum diujicobakan terkait konsep dasar, tahapan, instrumen pembelajaran serta instrumen penilaian berpikir kritis.

Pada tahap revisi desain bertujuan untuk memperbaiki produk atau melengkapi pembelajaran yang dikembangkan supaya mudah dipahami dan diimplementasikan. Adapun hasilnya berupa desain metode APITU2K baru dengan memunculkan kegiatan setiap kelompok secara rinci, seperti tersaji pada Gambar 3.

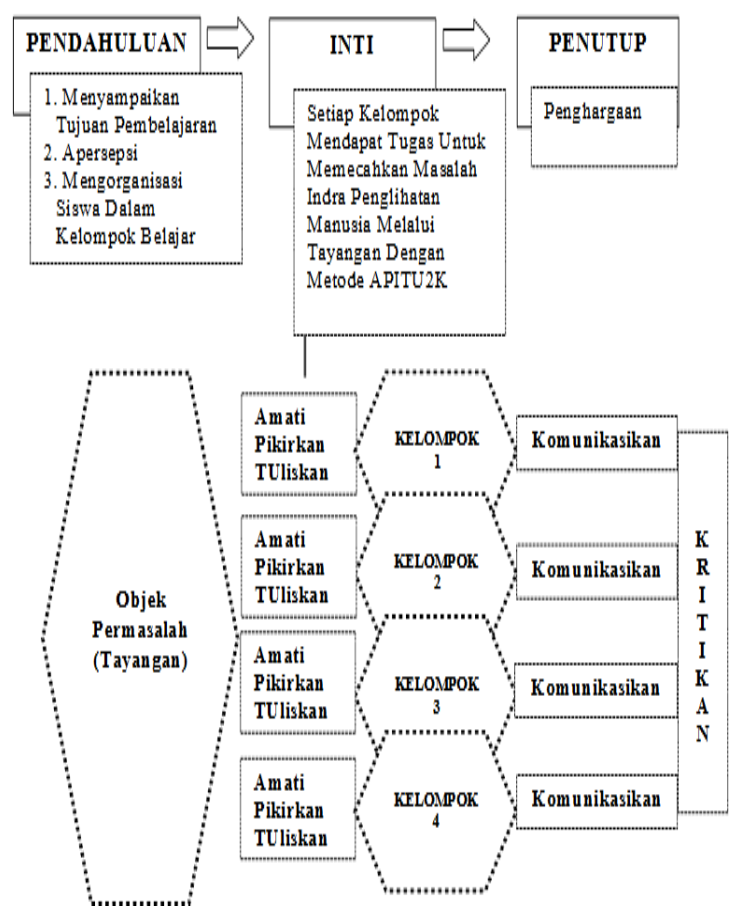

Gambar 3. Desain APITU2K revisi 1 
Quagga: Jurnal Pendidikan dan Biologi Volume 11, Nomor 2, Juli 2019

Pada tahap uji coba, dilakukan di kelas IX A yang berjumlah 28 siswa dengan alasan hasil belajar materi tentang indra pendengaran merupakan kelas dengan jumlah siswa yang paling banyak mencapai KKM.

Pada tahap revisi produk hasil uji coba, dengan memunculkan kegiatan secara klasikal terkait membuat kesimpulan yang dibimbing guru, seperti tersaji pada Gambar 4.

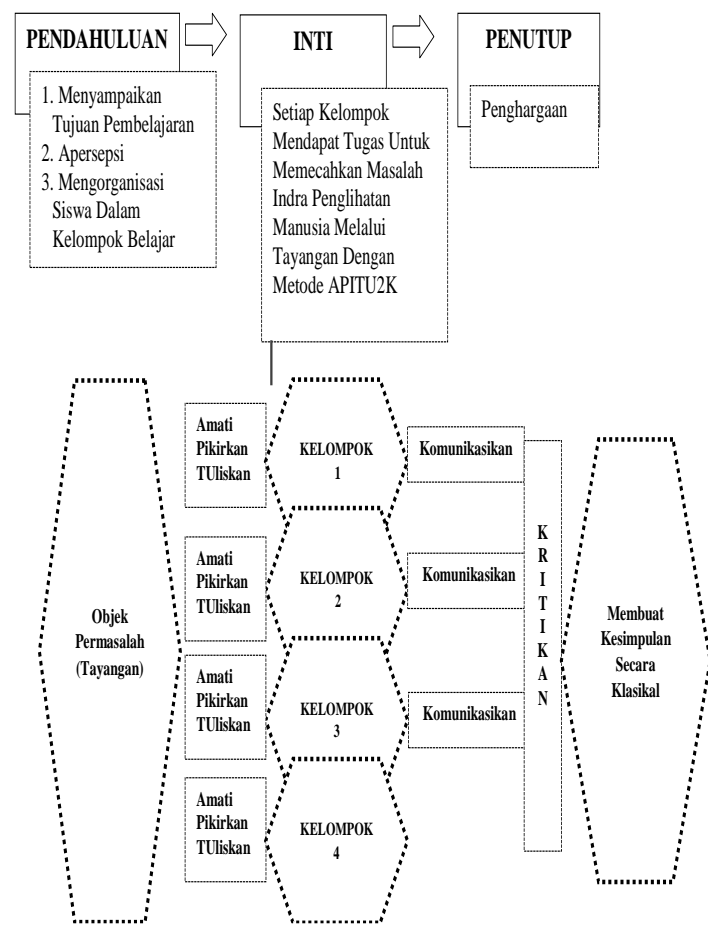

Gambar 4. Desain APITU2K revisi 2 (final)

Prototipe metode APITU2K menyangkut materi, fase pembelajaran, setting, langkahlangkah kegiatan seperti tersaji dalam Tabel 3

Tabel 3. Prototipe Metode APITU2K

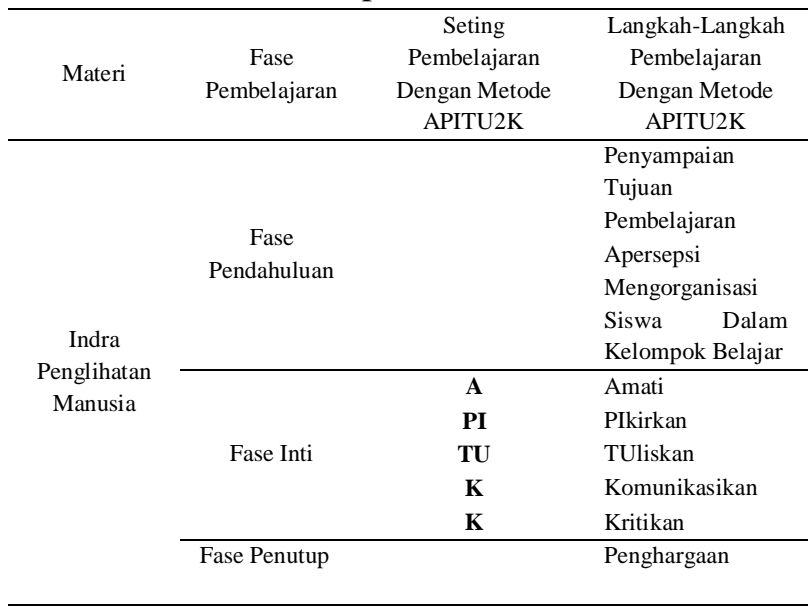

p-ISSN 1907-3089, e-ISSN2651-5869

https://journal.uniku.ac.id/index.php/quagga

\section{Implementasi Metode APITU2K}

Data tes berpikir kritis sebelum dan sesudah diterapkanya metode APITU2K melalui uji wilcoxon sign rank test di kelas IX C seperti terlihat pada Tabel 4.

Tabel 4. Hasil Uji Wilcoxon Sign Rank Test

\begin{tabular}{lr}
\hline & Postes - Pretes \\
\hline $\mathrm{Z}$ & $-3.712^{\mathrm{a}}$ \\
Asymp. Sig. (2-tailed) & .000 \\
\hline a. Based on negative ranks. \\
b. Wilcoxon Signed Ranks Test \\
\hline
\end{tabular}

Berdasarkan uji tersebut terlihat nilai $\mathrm{Z}$ sebesar -3.712 dengan p value (Asymp. Sig. (2tailed)) kurang dari batas kritis sebesar 0,05 sehingga dapat diputuskan terdapat perbedaan signifikan antara nilai pretes dan postes.

Rekapitulasi perbandingan nilai rata-rata berpikir kritis, ketuntasan, dan kriteria $\mathrm{N}$-gain divisualisasikan seperti pada Gambar 5.

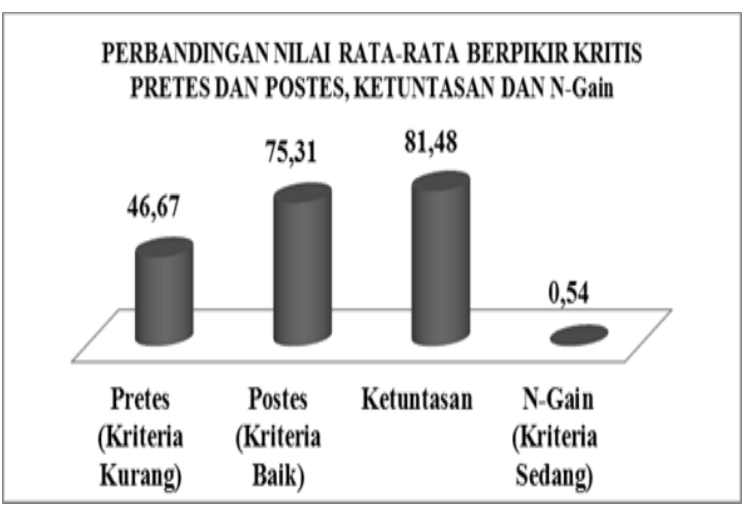

Gambar 5. Perbandingan nilai rata-rata berpikir kritis, ketuntasan dan kriteria $\mathrm{N}_{\text {gain }}$

Berdasarkan Gambar 5, terjadi kenaikan nilai rata-rata pretes $(46,67)$ dan postes $(75,31)$ dengan $\mathrm{N}$-gain 0,54 (kriteria sedang) dengan ketuntasan $81,48 \%$. Hal ini mengindikasikan bahwa metode APITU2K memberikan dampak dalam mengembangkan berpikir kritis siswa meskipun masih kriteria sedang. Namun melampaui kriteria ketuntasan belajar yang menjadi acuan yakni $75 \%$. Pembelajaran dengan fokus pemberian masalah di awal pembelajaran berdampak pada aktivitas kerja ilmiah siswa. Diawali dengan pengumpulan 
Quagga: Jurnal Pendidikan dan Biologi

Volume 11, Nomor 2, Juli 2019

informasi pada kerja ilmiah mengamati dan memacu siswa mengeluarkan pendapat melalui kerja berpikir serta berkerja untuk berinteraksi dengan orang lain .

Aktivitas mengamati masalah yang dilakukan siswa akan memunculkan beragam pertanyaan. Pembelajaran yang memberikan masalah awal kesiswa dapat memotivasi belajar mereka terutama mengajukan pertanyaan apa, mengapa dan bagaimana dengan mempertimbangkan sumber informasi yang dapat dipercaya dalam menyelesaikan masalah yang diberikan. Pada aktivitas berpikir, siswa menentukan masalah utama yang akan dipecahkan berdasarkan kemampuan dalam mengidentifikasi istilah untuk menyusun kesimpulan berdasarkan aktivitas berpikir. Menurut Khairah dkk (2017), bahwa terjadinya proses pemahaman (berpikir) dalam mengaitkan permasalah yang akan dipecahkan dengan informasi yang diperoleh melalui pengamatan mengenai sebuah peristiwa.

Pada tahap kerja ilmiah tuliskan, siswa menuliskan semua hasil berpikir hal ini dapat membuat siswa memahami terhadap materi yang sedang dipelajari. Ini sejalan dengan pendapat Siregar dkk (2017), bahwa menulis dengan menggunakan bahasa sendiri merupakan bentuk pemahaman terhadap konsep dalam materi yang sedang dipelajari.

Pada tahap kerja ilmiah komunikasikan, memberikan penekanan kepada siswa untuk mempresentasikan hasil tulisan ke kelompok lain. Tahapan ini siswa diberikan kesempatan untuk mempublikasikan hasil kerja melalui presentasi dan tanya jawab. Kegiatan ini menekankan upaya komunikasi hasil dari kemampuan metakognitif. Ini sejalan dengan pendapatnya Hasan dkk (2016), bahwa berkomunikasi akan melatih kemampuan siswa untuk memberdayakan keterampilan metakognitif yang mereka miliki.

Pada tahap kerja ilmiah membuat kritikan, merupakan upaya mengembangkan kemampuan menganalis pendapat kelompok lain serta dibandingkan dengan pendapat kelompoknya. Kemampuan memberikan masukan dan
p-ISSN 1907-3089, e-ISSN2651-5869

https://journal.uniku.ac.id/index.php/quagga

tanggapan yang konstruktif merupakan kerja ilmiah yang menekankan pada upaya menyusun argumen untuk melengkapi informasi dari tulisan kelompok lain. Menurut Rasmawan (2017), bahwa kritikan merupakan sebuah kemampuan menjelaskan makna yang sesuai dengan bahasa yang jelas dan logis serta dapat mengaitkan dengan konsep yang benar.

Rekapitulasi perbandingan $\mathrm{N}$-gain setiap sub indikator berpikir kritis dan kriteria divisualisasikan seperti pada Gambar 6.

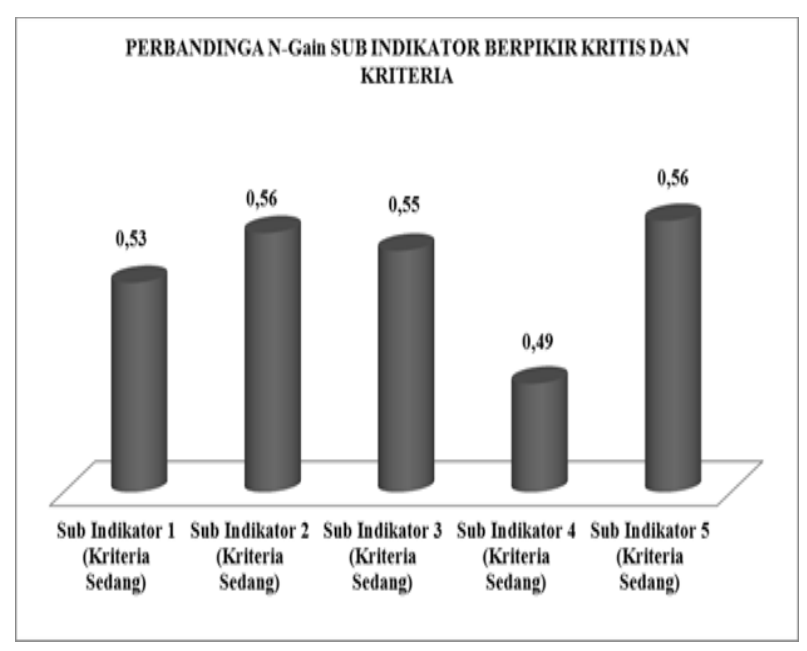

Gambar 6. Perbandingan N-gain Setiap Sub Indikator Berpikir Kritis Dan Kriteria

Keterangan

Sub indikator ke :

1:Bertanya dan menjawab pertanyaan yang menantang.

2:Mempertimbangkan

3:Membuat kesimpulan

4:Mengidentifikasi istilah

5:Berinteraksi dengan orang lain.

Berdasarkan Gambar 6, berdasarkan $\mathrm{N}$-gain semua sub indikator berpikir kritis berkriteria sedang. Hal ini mengindikasikan bahwa pembelajaran dengan metode APITU2K memberikan dampak dalam mengembangkan berpikir kritis siswa meskipun masih dalam kriteria sedang.

Terfasilitasinya kemampuan berpikir kritis siswa karena proses pembelajaran dengan metode APITU2K. Metode ini dapat membantu 
Quagga: Jurnal Pendidikan dan Biologi

Volume 11, Nomor 2, Juli 2019

siswa untuk meningkatkan hasil belajar kognitifnya. Peningkatan kemampuan berpikir kritis tersebut karena proses pembelajaran yang dirancang oleh guru berupa metode APITU2K dapat membantu siswa untuk merangsang pengembangan kemampuan berpikir kritis. Dimana dalam proses pembelajarannya siswa diajak untuk menemukan suatu permasalahan yang ada pada materi indra penglihatan dan menemukan pula sendiri bagaimana proses pemecahan masalah melalui diskusi yang memberikan peluang untuk bertanya, mengecek sumber yang dapat dipercaya, mengidentifikasi dan saling berinteraksi untuk tukar menukar informasi atau pikiran dalam mengelola informasi terkait pemecahan masalah. Ini sejalan dengan pendapat Rasmawan (2017) bahwa siswa perlu dilatih keterampilan kerja ilmiah dan berpikir kritis, sehingga dalam hal ini siswa benar-benar dilatih untuk mengembangkan kemampuan berpikirnya.

Pemecahan masalah diawali dengan cara mengamati merupakan upaya menggali informasi sebanyak-banyaknya lalu dianalisis melalui aktivitas berpikir melalui pertanyaan-pertanyaan yang menantang serta menggali sumber yang dapat dipercaya dalam mencari jawaban dari permasalah yang diangkat. Siswa dituntut belajar secara kritis dalam menggali informasi untuk memecahkan masalah. Aktivitas kerja ilmiah APITU2K dalam kelompok sebaya akan menjadi warna bagi siswa untuk mengaktualisasikan potensi diri dalam meningkatkan kemampuan berpikir kritis. Ini sejalan dengan pendapat Rasmawan (2017), bahwa keterampilan mengolah informasi atau konsep-konsep yang dipahami untuk menjawab masalah merupakan salah satu ciri dari kemampuan berpikir kritis.

Pembelajaran dengan metode APITU2K membuat siswa secara aktif melakukan aktivitas APITU2K di dalam proses pembelajarannya. Dalam penyelesaian masalah yang terdapat pada LKS, siswa secara aktif mengajukan pertanyaan atau masalah, pengumpulan informasi yang relevan sebagai dasar berpikir dalam memberikan penjelasan terhadap data yang diperoleh. Hasil diskusi
p-ISSN 1907-3089, e-ISSN2651-5869

https://journal.uniku.ac.id/index.php/quagga

menyanggkut jawaban atas masalah akan mendapatkan masukan (kritikan) yang konstruktif melalui kemampuan mengkomunikasikan hasil yang diperoleh dalam pembelajaran. Pembelajaran dengan metode APITU2K difokuskan pada suatu masalah dapat membuat siswa memanggil kembali informasi-informasi awal yang mereka miliki dan berupaya untuk mengumpulkan informasi tambahan untuk membuat jawaban terhadap masalah yang dipecahkan.

Metode APITU2K menuntut kepedulian berinteraksi dengan siswa lain untuk memecahkan permasalahan tersebut. Adanya diskusi kelompok maupun klasikal akan lebih meningkatkan pemahaman akan materi walaupun terjadi kesalahan konsep pada siswa guru dapat memperbaikinya saat diskusi kelompok/kelas.

Kendala dalam pembelajaran menggunakan metode APITU2K tentang indra penglihatan manusia untuk meningkatkan kemampuan berpikir kritis siswa terlihat pada masih ditemukan kesulitan siswa melakukan kerja ilmiah APITU2K, kurang kesiapan belajar terkait pengetahuan awal materi, masih adanya dominasi salah satu anggota, belum ada keberanian untuk mengemukakan ide atau pendapat dan belum mampu memanfaatkan waktu yang disediakan sehingga mengganggu pelajaran berikutnya.

\section{SIMPULAN}

\section{Simpulan}

1. Dihasilkan bentuk metode APITU2K dalam memecahkan masalah indra penglihatan manusia.

2. Hasil belajar berupa berpikir kritis siswa menunjukkan nilai rata-rata postes 75,31 dengan kriteria baik, ketuntasan $81,48 \%$, dan $\mathrm{N}$-gain sebesar 0,54 dengan kriteria sedang. Berdasarkan uji wilcoxon sign rank test nilai $\mathrm{Z}$ sebesar -3.712 dengan $\mathrm{p}$ value (Asymp. Sig. (2-tailed) sebesar .000<0,05 sehingga dapat diputuskan terdapat perbedaan signifikan antara nilai pretes dan postes. Dengan demikian dapat disimpulkan bahwa metode APITU2K dalam memecahkan masalah indra penglihatan manusia dapat 
Quagga: Jurnal Pendidikan dan Biologi

Volume 11, Nomor 2, Juli 2019

meningkatkan berpikir kritis siswa kelas IX C SMPN 1 Karangkancana tahun pelajaran 2018/2019.

\section{Saran}

Perlu pelatihan beberapa kali mengenai kerja ilmiah APITU2K agar siswa terbiasa belajar mandiri dan mempertimbangkan kebenaran sumber yang mengandung masalah disekitar kehidupannya. Serta dapat memecahkan masalah aktual dengan menggunakan konsep-konsep yang siswa pelajari dari buku.

\section{REFERENSI}

Dahar, R.W. (2011).Teori Teori Belajar \& Pembelajaran. Jakarta : Erlanggga.

Ennis, Robert. H. (2011). The Narture of Critical Thinking : An Outline of Critical Thinking Dispositions and Abilities. University of Illinois.Part I. Inquiry, 26(1)

Hasan, A.N., Mahardika, K., Yushardi.(2016). Pengembangan Model Pembelajaran TPAC (Think, Pair, Analyze, Comunicate) Untuk Pembelajaran IPA Di SMP. Prosiding Seminar Nasional Pendidikan IPA Pascasarjana Universtas Malang (hlm. 100-104). Malang:UM Press.

Kementrian Pendidikan Dan Kebudayaan.(2013).Materi Pelatihan Guru Implementasi Kurikulum 2013 SMP/MTs Ilmu Pengetahuan Alam Modul PelatihanImplemetasi Kurikulum 2013. Jakarta : Kementrian Pendidikan Dan Kebudayaan

Khairah, D.I.U., Mudakir, I., Wahono, B.(2017). Penerapan Model Pembelajaran Kooperatif Tipe Think Talk Write (TTW) Untuk Meningkatkan Hasil Belajar Siswa Kelas VIII D SMPN 1 Mangaran. Jurnal Edukasi, 4(3), hlm. 6-9
p-ISSN 1907-3089, e-ISSN2651-5869

https://journal.uniku.ac.id/index.php/quagga

Rahayu, Y.S. (2012). Pengaruh Penggunaan Metode Pembelajaran Synergetic Teaching (Pengajaran Sinergis) Terhadap Kemampuan Berpikir Kritis Siswa Pada Konsep Pencemaran Lingkungan Di Kelas X SMA Negeri 1 Luragung. (Skripsi), Jurusan Pendidikan Biologi FKIP Universitas Kuningan, Kuningan.

Rasmawan, R.(2017). Profil Keterampilan Kerja Ilmiah Dan Berpikir Kritis Siswa. Edusains, 9(1), hlm. 60-70

Rosdianto, H., Murdani, E., Hendra.(2017). Implementasi Model Pembelajaran POE (Predict Observe Explain) Untuk Meningkatkan Pemahaman Konsep Siswa Pada Materi Hukum Newton. Jurnal Pendidikan Fisika, 6(1), hlm. 5557

Siregar, I.Y., Susilo, H., Suwono, H. (2017). Pengaruh Think-Pair-Share-Write Berbasis Hybrid Learning Terhadap Keterampilan Metakognitif, Berpikir Kreatif Dan Hasil Belajar Kognitif Siswa SMA Negeri 3 Malang. Jurnal Pendidikan Biologi Indonesia, 3(2), hlm. 183-193

Sugiono. (2012). Metode Penelitian Pendidikan Pendekatan Kuantitatif, Kualitatif dan $R \& D$. Bandung: Alfabeta

Univeritas Pendidikan Indonesia.(2011).Bahan Ajar Ilmu Pengetahuan Alam SMP/MTs Pendidikan Dan Pelatihan Profesi (PLPG) Rayon 110 . Bandung : UPI 